\title{
CHEKHOV AND THE ANNAS
}

This piece originally appeared in the festschrift Life and Text. Essays in Honour of Geir Kjetsaa on the Occasion of his 60th Birthday, edited by Erik Egeberg, Audun J. Mørch, and Ole Michael Selberg (Oslo 1997).

\section{CHEKHOV AND THE ANNAS}

(1997)

- Отчего я не сплю по ночам?

- Не знаю, милая. А когда я не сплю по ночам, то закрываю глаза крепко-крепко, вот этак, и рисую себе Анну Каренину, как она ходит и как говорит...

"Невеста"

На этот раз Лаевскому больше всего не понравилась у Надежды Федоровны ее белая, открытая шея и завитушки волос на затылке, и он вспомнил, что Анне Карениной когда она разлюбила мужа, не нравились прежде всего его уши, и подумал: «Как это верно! как верно!»

“Дуэль”

"In Anna Karenina and Evgeny Onegin not a single question is solved, but they satisfy fully because questions are posed correctly."

Chekhov to Alexei Suvorin, 27 October 1888

How did Chekhov respond to Anna Karenina? Most scholarly attention has been devoted to Chekhov's struggle with Tolstoyanism. His early infatuation with Tolstoy's moral precepts was eventually followed by the "counterstories": "Skučnaja istorija" [A Boring Story] as a more honest reflection 
of the dying process than "Smert' Ivana Il'iča" [The Death of Ivan Ilyich]; "Mužiki" [Peasants] as the non-sentimentalized picture of peasant life that the aging Tolstoy was reluctant to tell; "Palata No. 6" [Ward No. 6] as the real, ghastly result of non-violent resistance to active evil. Finally, in a number of letters after his return from Sakhalin peaking with the Kreutzer Sonata scandals, Chekhov emancipated himself from the Tolstoyan "hypnosis." The usual approach to this evidence has been to trace the struggle between a mature, maximally flexible Chekhov at the height of his powers - and the late, didactic, maximally inflexible Tolstoy, a great writer who had come to distrust many types of art deeply. ${ }^{1}$

This juxtaposition of two "contemporaries in person" (that is, meeting in the same time, although Chekhov was by three decades the younger man) is powerful, but inevitably skewed. My concern in this essay is to look at an earlier wedge of the relationship. For Chekhov also responded to a more tractable Tolstoy, Tolstoy before those polemics against art and sex had become so single-minded. This response took the form of a literary "reply" — not to a hardened ideology, but to a masterpiece that the younger writer deeply admired. In at least half-a-dozen stories, all from the 1880s-90s, Chekhov takes on the challenge of the Anna Plot. He recombines its couples, reaccents its themes, alters the timing of its events. Three of the most famous stories - "Dama s sobačkoj," "Anna na šee" and "O ljubvi" — have heroines named Anna. Repeatedly, crucial events take place on or near railway trains. Some involve "first balls" where one falls in and out of love, and others exploit that Tolstoyan moment when a freshly-unloved partner is suddenly seen in a new, less sympathetic way (Karenin's ears that so irritate Anna upon

The affected years - when Chekhov acknowledged he was under Tolstoy's influence were 1882 to 1894 . During the initial period, Chekhov produced stories that were direct reflections of Tolstoyan ideology and, as art, rather weak ("Khorošie ljudi," "Niščij," "Kazak," "Pis'mo"); then, after transitional explorations of Tolstoyan ideology in practice (such as "Moja žizn"), the famous renouncing letters: to Pleshcheev, 15 February 1894, about Tolstoy "out of sheer stubbornness... not taking the time to read two or three pamphlets written by specialists;" and to Suvorin, 27 March 1894, "Tolstoyan morality has ceased to touch me profoundly [it was not the precepts themselves that had affected me but] the way Tolstoy expressed himself, his immense common sense, and, no doubt, a sort of hypnosis. But now something inside me challenges it." For surveys in English see Beverly Hahn, Chekhov: A Study of the Major Stories and Plays (Cambridge: Cambridge University Press), ch. 7, "Chekhov and Tolstoy;" Sophie Laffitte, Chekhov: 1860-1904 (New York: Charles Scribner's Sons, 1971), ch. 18, “Tolstoyan Interlude”; Ronald Hingley, A Life of Anton Chekhov (Oxford: Oxford University Press, 1989), ch. 11, "Melikhovo, 1892-97". 
her return to Petersburg). All of the stories confront head on that complex of assumptions Tolstoy made about the sinfulness of sexuality - especially Anna's moment of physical "Fall" with Vronsky presented by Tolstoy as shame, nakedness, spiritual death and expulsion from the Garden of Eden.

One comment on methodology. We know that Chekhov sharpened his craftsmanship in the 1870 s and 80 s by writing a large number of literary parodies - of Gogol, Lermontov, Turgenev, as well as a host of lesser hack writers. ${ }^{2}$ Parodies can be respectful, affectionate, dismissive, abusive, but whatever the intent, an author can embed references to an earlier authoritative plot in several ways. Easiest (and most comic) is to have fictional characters in distress make reference to the earlier canonized plot, hoping thereby to escape responsibility for their own shoddy intentions or behavior by identifying a famous prototype. Such, for example, is Laevsky's famous remark in "The Duel" about his mistress Nadezhda Fyodorovna's white neck and curls reminding him of Anna Karenina's distaste for her husband's ears; or, in “The Bride" [Nevesta], Nina Ivanovna's remark to her daughter Nadia that, during bouts of insomnia, she comforts herself by thinking how Anna Karenina walks and talks. More difficult, surely, is to sustain a retell of the prior narrative throughout the entire newly-authored plot, re-accenting it at multiple points and questioning the entire reasonable basis or moral integrity of that earlier world. In his Anna stories, I believe, Chekhov took on this larger task. But in addition to testing Tolstoy, these tales provide another service: they illustrate various ways by which prose writers can achieve a "realistic effect."

One route to realism is that of the $19^{\text {th }}$-century mega-novelist. This was the way of Dickens, Balzac, Trollope, George Eliot, Tolstoy: pile up detail, fill in the landscape, saturate the reader with author's commentary, narrator's insights, characters' perspectives or potentials. But working in the short form, Chekhov had no space or time for that. How might a realistic sense of breadth and multiple options - the sense of a genuinely open world - be realized in a compact form? Not wishing bulk, such writers could still achieve that "open effect" by eroding or undermining a stereotype. Chekhov could use Anna Karenina in this way because Tolstoy's famous novel, by the 1880s, had become an "infidelity stereotype." The briefest invocation of its story, via easily recognized motifs (black curls, squinting eyes, prominent ears, trains), could set the stage for an estrangement or a re-emphasis of the

2 See Karl D. Kramer, The Chameleon and the Dream: The Image of Reality in Cexov's Fiction (The Hague: Mouton, 1970), ch. II, “Literary Parodies," 28-48. 
plot. This new, barely sketched-in world would then suggest options without having to prescribe them or exhaustively fill them in. Such a suggestion of alternative fates for a familiar, given set of character-relations could be seen as a re-novelization (in Bakhtin's sense) of Tolstoy's canonized plot - and thus, paradoxically, Chekhov's modest short-story variants could be seen to enact the "spirit of the novel" on a novel.

With this dynamic in mind, let us consider some stories. Each takes on one large, stubborn aspect of the mature Tolstoyan worldview. But it is Tolstoy mediated through a mid-career novel where that worldview is not yet ossified (as it will be for the narrator of Resurrection) - where it is still, as it were, softer cartilage, subject to the malleability and tenderness of competing interpretations. Chekhov, so great a master at the malleable and the tender in human relations, opens Tolstoy's novel up to new confusions and compassions. Konstantin Levin might not have been so lucky. Anna's terrible denouement might be avoided. There will be a price, of course, for doing so, for suicide is an elegant one-way gesture and splendid closure; but that too is part of Chekhov's re-novelization. Chekhov and Tolstoy had different ideas about closing things down.

The simplest and most lapidary re-write of the Anna plot, one could argue, is the 1886 story "Neščast'e" [A Calamity]. The story, told from the woman's point of view, is packed with trains, with flirtations around train stations, and features an unresponsive husband as well as a child who suddenly appears disappointingly graceless to the mother in the afterglow of an illicit preliminary tryst. The heroine, Sofya Petrovna, married and with a daughter, has been pursued for some time by the lawyer Ilyin. His helpless, humiliating passion for her eventually wears her down and simultaneously arouses her. By the end of the story she is driven to seek him out, driven by something “сильнее и стыда ее, и разума, и страха..." [stronger than shame, or reason, or fear]. That something is lust, and in this physiological sketch Dr. Chekhov arguably administers to Tolstoy a lesson in ordinary female sexuality and its strategies of fulfillment. Its counter-scene in the novel is Anna's "fall" with Vronsky, described melodramatically and morbidly, or perhaps the later Pozdnyshev's bizarre insistence that women instinctively dislike the carnal relation. To be sure, Sofya Petrovna is not proud of her behavior (to that extent the story unfolds under the star of Tolstoy); she is disgusted by her own duplicity, condemns herself for this frivolous behavior so injurious to her vanity, and is forced to acknowledge her ordinariness. Consummation of the affair with Ilyin, which lies just beyond the boundaries of the story, is not heroic, sacrificial, suicidal - all Anna Karenina motifs; 
it is quite possible, Chekhov suggests, to consummate and to go on living, perhaps more honestly than before.

One subtext to the title "Neščast'e" might be Tolstoy's early work "Semejnoe sčast'e," also written by a man from a woman's perspective. But with this important inversion: Tolstoy's tale ends precisely where the family unit - with its disillusions, displacements and the obligations of parenting - claims total rights. Chekhov's story is not "семейное" at all, but rather a serious treatment of the one thing Tolstoy (who was endlessly interested in his own sexual behavior) so often manages to evade - female desire and all its embarrassing dynamics: seduction, shame, cowardice, curiosity, temporary resistance and ultimate acquiescence. In Anna Karenina, the train and its murderous potential had put a glorious, tragic stamp on the heroine's whole ruined life. In Chekhov's understated "Calamity," train imagery makes the heroine not demonic, tragic, operatic, but simply ordinary, like everyone else, precisely not a novelistic heroine. When Sofya Petrovna first hears, during her flirtation with Ilyin, the "сиплый... свист локомотива" [the hoarse whistle of the locomotive], it does not signify the high symmetrical poetry of Anna Karenina, where a fatal train accident early in the novel prefigures what a frantic Anna "knows she must do" at the end. In Chekhov, it remains the random sound of а "товарный поезд," a freight train. This whistle brings her to her senses; for it is, as Chekhov writes, the "extraneous, cold sound of everyday prose" [посторонний холодный звук обыденной прозы]. Chekhov's "Neščast'e" - and the title may or may not be ironic - is the story of a genuinely prosaic, not a poetic, consummation.

Is this a good or bad thing, Sofya Petrovna's "fall?" Chekhov does not pass judgment; Sofya does enough of that on herself. "Neščast'e" triggered widely disparate opinions in the Russian press. How wonderfully you are able to express love "in all its most subtle and sacred manifestations," Grigorovich wrote to Chekhov in December 1880; Bilibin, on the other hand, was moved to remark à propos of the story: "To hell with the whole poetic side of love!"3 Our next re-write is very much in Bilibin's spirit, namely, the Anna plot in a totally cynical key.

That story, written in 1895, is one of Chekhov's darkest: "Anna na šee" [Anna Round the Neck]. Here too we have trains (the bride and groom first know each other physically in a couchette); here too we have a radiant heroine at her first ball, and the world of love contrasted with the world of grey

3 For these letters, see the commentary to the story in A. P. Chekhov, Собрание сочинений в 12-и томах (Moscow: 1961), 4:550-51. 
officialdom. But the Anna Petrovna of the opening pages, married at 18 to pompous Modest Alexeich who is over twice her age, already resembles - on her wedding day - Tolstoy's Anna at the end of the novel, a woman in moral decline. Chekhov has chosen an intriguing starting point. For one of the fascinating, surely calculated lacunae in Tolstoy's very long Anna Karenina is its almost total silence on Anna as newlywed. What little we hear comes late in the novel and tucked into Alexei Karenin's story, already hopelessly alienated from the consciousness of the heroine. Whether or not the Karenin marriage was a "good" one when we meet it (and marriages can be good, self-respecting and self-sustaining, without being passionate) is still much debated. But how did it start out? We eventually learn that Anna Oblonskaya was beautiful but not a profitable match; that Karenin had visited her often enough to make a proposal the proper thing to do; but of the drive or curiosity of love, marital or extramarital, we are told nothing. In contrast to that shrouded pre-history, Chekhov's just-married Anya is all drive and curiosity. She flirts with Artynov straightaway at the railway station, coquettishly "screwing up her eyes” [прищурила глаза], whereas Anna Karenina, we recall, begins this practice only in her final months of self-deception. When Tolstoy's Anna Arkadievna acts this way, we sense tragedy, her need to screen out the truth. Chekhov's Anna Petrovna is incapable of tragedy. Except for the leitmotif of her alcoholic father and two pathetic brothers, all increasingly distanced from Anya's life and eventually forgotten, there are no victims in the story at all. Chekhov's fictional world is morally akin to Tolstoy's Petersburg, peopled entirely with Sappho Stolzes and Betsy Tverskaias. Indifferent to fidelity, to family, and to love, all parties are satisfied - including, of course, the betrayed husband, who uses his wife to rise in the service. There is more than a hint here of Russian high society during Pushkin's earlier, unabashedly licentious era, far more "French" and dry-eyed about sexual access and calculated liaisons. To be sure, Anna Petrovna's self-serving behavior is perhaps better justified than the empty-headed antics of Sappho Stolz. But that we can never know for sure, because Tolstoy was quite unable to tell any neutral stories from the perspective of the likes of Sappho - any more than he could have related Sofya Petrovna's "fall" in the Chekhovian manner of "Neščast'e," that is, from within that woman's own frustrated, hungry and fed-up zone. Chekhov specializes in just such "speech from within the zone."4

4 Writing in the afterglow of the great tendentious novelists, Chekhov was quite canny in his defense of this "objective" prerogative. For him, presenting characters in their own voice and value zone was not only efficient; it was also more authentically ethical. See 
In "Anna Round the Neck," the lowest point in the heroine's marriage is reached right before her success at the ball. She is poor (although she had been married for the money), unfree, unloved. Chekhov tells us that Anna Petrovna's husband reminded her of all those oppressive authorities who, "with an insinuating and terrible force, moving in on her like a storm cloud or a locomotive, were ready to crush her" [как туча или локомотив, готовый задавить]. That is the Tolstoyan Anna's recurring bad dream, but this Anna will confront it and overcome it. The morning after the social triumph that insures her independence, she greets her husband with “подите прочь, болван!" [Out of my sight, you fool!]. And we learn that Anna Petrovna finally feels free: the "ancient terror before that force, which moved in on her and threatened to crush her, now seemed to her ridiculous" [казался ей смешным].

But is this really a triumph, is there no external reminder of the ethical dimension? In Tolstoy's novel the moral measurement is always family - and usually children. Anna's young son Seryozha feels awkward around Vronsky, not knowing Vronsky's role in the household but sensing his mother's passionate awareness of him; more importantly, Anna and Vronsky feel guilty around Seryozha, for he (Tolstoy tells us) is the compass showing them how far they have strayed off course. In Chekhov's tale, family is either shoved out of the picture altogether (her drunken father and anxious younger brothers, with their refrain, "Папочка, не надо..." [Рара, don't]), growing ever more faint, or else the idea of family and children is parodied grotesquely on the bodies of the married couple. The "Anna" that the wife becomes around Modest Alexeich's neck and the "little Vladimir" to which his Excellency is to stand godfather are state decorations. Chekhov is giving us a picture of the high-society world as it should run-according to the values of, say, Madame Vronskaia, who belongs wholly to that world and behaves obediently within it. As she sees her devastated son off to the wars, you recall, Madame Vronskaia remarks of Anna Karenina's suicide: “But why,

the letter to Alexei Suvorin (1 April 1890): "You upbraid me about objectivity, styling it indifference to good and evil, absence of ideals and ideas, etc. You would have me say, in depicting horse thieves, that stealing horses is an evil. But then, that has been known a long while, even without me. Let jurors judge them; for my business is only to show them as they are... Why, in order to depict horse thieves in seven hundred lines I must constantly speak and think as they do and feel in keeping with their spirit; otherwise, if I add a pinch of subjectivity, the images will become diffuse and the story will not be as compact as it behooves all short stories to be. When I write, I rely fully on the reader..." Cited from Letters of Anton Chekhov, selected and edited by Avrahm Yarmolinsky (New York: Viking, 1978), 133. 
I ask you, all these desperate passions? Whatever you say, she was a bad woman: ruined herself and two splendid men." Chekhov's Anya will never have that sin on her conscience.

In our final two rewrites, the entrapment of the Chekhovian hero and heroine is presented with more redeeming moral features. While still incapable of big, tasteless, desperate action, the men and women involved in these plots do not entirely give up, nor do they give in; and thus the stories are among Chekhov's most haunting masterpieces. The first (and perhaps most famous of all the Anna tales) is the story of Anna Sergeyevna and Dmitri Gurov in "Dama s sobačkoj" [Lady with a Pet Dog]. Here too, we have our share of trains and theaters, but there is none of the clinical coldness of "Neščast'e" or "Anna na šee." "Dama s sobačkoj" is a genuine love story, one of the world's greatest, in which Chekhov mixes Tolstoyan prototypes, and at times Tolstoyan diction, to achieve a new perspective on adultery and responsibility.

The plot everyone knows. But what about the human material, if measured against Tolstoyan character-types? Gurov resembles a Vronsky, or perhaps an Oblonsky, and Anna Sergeyevna is a timid, inexperienced Kitty. But there is this important difference at the outset: neither Gurov nor Anna Sergeyevna are free (both have Karenin-like spouses). Also, neither expects nor is prepared for the abiding seriousness of their affair. One way to read this seriousness is to see the first two chapters - up to Anna Sergeyevna's departure, on a train, for home, and Gurov's plans to leave Yalta for Moscow soon after - as written in the voice zone of a young Vronsky or Oblonsky, from the light philandering perspective of an experienced male on "ты" [thou] with his girl while she is still on a tremulous "вы” [уоu] with him. Chapter 2 concludes one sort of infidelity plot, a "serial" structured to repeat, but not to grow more profound, with a new cast. But then comes the second half of the story. Chapters 3 and 4 witness real love that grows unexpectedly out of this stereotypical beginning - much as Anna and Vronsky's love had become creative, expansive, and "real" by the mid-parts of Tolstoy's novel. The dependencies are now mutual. Gurov tracks Anna Sergeyevna down in the city of S., after which she begins to come to Moscow. A rhythm is established that reflects a deep, and deepening, fidelity. The story ends on the word "начинается," beginning. This inconclusive ending is perhaps a type of tragedy, but with no tragic climax or closure - and its very stability becomes a moral achievement.

The key to the change worked on Tolstoy's worldview comes at the end of the story, with Gurov's meditations en route to the Slaviansky Bazaar 
where Anna is waiting. As he walks, he explains how thunder works to his daughter; in his thoughts he is elsewhere. His ruminations concern a human being's inevitably "double life," the fact that the way we act in the world is not what we are. Gurov concludes that this is a very good thing, for "каждое личное сосуществование держится на тайне" [every personal co-existence is sustained on a secret]. The whole binary tone of the passage, with its frequent repetitions of phrase, recalls Tolstoy's style - but the moral is purely Chekhovian. For Tolstoy, the secret could not be wholly sustained; sooner or later there would be an integration between inner and outer. The false life would have to be brought into line with the true life before a spiritual epiphany could occur (what Ivan Ilyich glimpses before death, or Konstantin Levin experiences at the end of the novel). The Tolstoyan self, in this resembling the Tolstoyan image of humanity, strives toward wholeness. Like poor Anna Karenina, that self wishes to "have it all" - lover, son, social respect, constant access to the beloved, unchanging and unaging beauty. When Anna cannot have it all, she self-destructs. The Chekhovian self is far more modestly constituted. Its credo is not self-perfection and self-completion but rather the lesson (dear to Turgenev as well) taught by those sea waves on the Oreanda beach: the "шум моря" [noise or humming of the sea], which displays an indifference to the life and death of each of us and thus holds out the promise of our salvation. In Tolstoy, indifference and compromise could never bring salvation. And thus the inadequate, makeshift, purely private and secret structures that sustain true love in "Dama $s$ sobačkoj" could not, for Tolstoy, be an acceptable moral resolution.

The final entry in this pantheon of Anna rewrites is, to my mind, the deepest and most perfect: "O ljubvi" [About Love], the third story in Chekhov's 1898 "Malen'kaja trilogija." The story is Alyokhin's account of his unconsummated passion for Anna Alexeyevna, wife of his friend Luganovich. It is framed by his confession, years later, that his failure to consummate this love was probably a mistake. Allusions to Tolstoy's cast of characters are everywhere, but this cast is scrambled, differently matched up, ill-served by life's timing. The basic realignment is as follows. In "O ljubvi" a Levin and a Kitty fall in love - both decent, modest, proper people, committed to responsible behavior - but after she has married someone else. This is the plot that might well have happened in Tolstoy's novel if Tolstoy had not so conveniently taken Kitty out of circulation (ill from Vronsky's jilt of her, she was sent to a spa abroad) until his alter-ego and author's pet, Konstantin Levin, had time to recover from his pout over her rejection of him - if, that is, Kitty had married someone else before Levin could get back 
to her. Chekhov's Alyokhin carries many of Levin's traits and virtues (his patronymic is Konstantinovich): he is a loner, an intellectual turned farmer, an "educated man rushing about and working hard in the country." He falls in love with Luganovich's wife, and she with him. But, being neither Anna Kareninas nor Vronskys, not possessing that heroic initiating power that breaks through to its desired object regardless of cost - they continue, over several years, to "do the right thing," which is to do nothing.

Irritations and tensions increase, to their mutual distress. Alyokhin cannot speak of his love because of his code of honor (Levin's circle, after all, is not Vronsky's); Anna Alexeyevna cannot speak of love because, as Chekhov put it, "she would either have to lie, or tell the truth, and in her position both would be equally inappropriate and terrible." There is insufficient selfishness at work here to launch the Anna plot. What energy there is, is employed to fight against that plot, in the larger interest of kindness and prior commitments. Thus they are spared Anna's and Vronsky's terrible denouement. But "O ljubvi" still ends on a train scene-and it is for the reader to judge whether this scene is a victory or a defeat. In the coach, saying farewell, they finally confess their love. Relating the story years later, Alyokhin remembers this parting with bitter pain. "When you love," he concludes, "in your reasoning about that love you must proceed from something higher and more important than happiness or unhappiness, sin or virtue in their usual sense, or you must not reason at all."

"... Или не нужно рассуждать вовсе" [or you must not reason at all]: a more non-Tolstoyan maxim could hardly be imagined for a story about extra-marital love. What makes "O ljubvi" such a fine reworking of Tolstoy? Not only does its programmatic title evoke Tolstoy's own preemptory titles for his didactic essays - "O vojne," [On war], "O religii" [On religion] "Tak čto že nam delat'?” [What then must we do?], “Čto takoe iskusstvo?" [What is art?"]; also, it challenges the whole crafty enterprise of Tolstoy as "prosaicist." For several years now, Gary Saul Morson has been elaborating on the prosaic values, virtues and plots in Tolstoy. ${ }^{5}$ Tolstoy's prosaic heroes are the unheroic ones, Morson argues, the ones who live without melodrama, without fixed or noisy rules, but with strongly disciplined mental and moral habits. Bad things do happen to these heroes,

5 Two prime texts for Tolstoyan prosaics are Gary Saul Morson, Hidden in Plain View: Narrative and Creative Potentials in "War and Peace" (Stanford: Stanford University Press, 1987), esp. ch. 5 and 7; and Gary Saul Morson, "Prosaics and Anna Karenina," in Tolstoy Studies Journal I (1988): 1-12. 
to be sure - Levin loses his Kitty in the first few chapters - but they suffer through misfortune in all the right, small ways, just as Anna Alexeyevna and Alyokhin do in "O ljubvi." They remain kind, they attend to particulars, they resist inflating their moods, they know how to take their pleasure in healthy distractions like hunting, farming, nursing the sick. And in Tolstoy's world - here is the point I wish to stress - good things come to them. Awkward, rebuffed Levin gets his Kitty, even though he had stupidly interrupted his initial courtship and fled Moscow, confusing all parties; that glorious moment comes when he enters the Oblonsky drawing room and realizes that Kitty (still free, fresh, flushed) is "waiting for him alone." This is a prosaicist's paradise, and Gary Saul Morson is certainly correct in saying that Tolstoy was drawn to it. In his fiction, Tolstoy plots this world carefully. He teases his Konstantin Levin and sets him back, but in the end, since Levin so completely embodies his author's most cherished values, Tolstoy sees to it that the good things come.

It took a very different sort of writer, one without Tolstoy's stubborn instinct for the moral shape of plots, to show the truly dark side of a virtuous prosaics. We have such a writer in Anton Chekhov, and - as I have tried to suggest - in Chekhov's various reworkings of the Anna Plot. Alyokhin and Anna Alexeyevna act like virtuous Levins and Kittys, and the good things do not come. This is not a question of Chekhov being a "pessimist" and Tolstoy a singer of nature, in whose works (more life-like than life itself) "things happen naturally." Nothing could have been easier, more prosaically normal, in Tolstoy's novel than to enact the "O ljubvi" plot: that is, to have Kitty — an attractive princess and prime marriage material - already recovered and married by the time Levin's hurt pride was healed. After all, if she fell in love with a Vronsky, she could easily fall for another man of his omnipresent sort. Tolstoy will not allow that to happen.

Chekhov, however, will allow it to happen - and this is what makes reading Chekhov so terribly real, and so very sad. Chekhov understood how virtuous prosaic living often turned out: a muddle, a mess, full of casual mistimings that become permanent tragedies, at times even denying people a decent memory by which to organize psychological material. For Tolstoy, prosaic values, "living right" minute by minute, simply had to work out - and he would fabricate all manner of authorial scaffolding to pair off the good folks and reward them. Even the unsung Dolly loves her ridiculous Oblonsky and continues to bear, nurse, raise, and bury his children throughout the novel, thus confirming her in her own best self until a passing comment from the author at the very end hints that she 
has finally, perhaps, had enough. Tolstoy might appear "realistic" and "nonromantic" in his focus on the small and decent gesture. But then Tolstoy makes certain that this gesture does not just get lost, or disintegrate, or pass unnoticed, or cause pain. That is Chekhov's terrain. ${ }^{6}$ Chekhov is full of people who do their best - but this does not deter him from casting his heroes and heroines back onto more helpless, weaker, altogether less rewarded sides of themselves. As Chekhov outgrew Tolstoy throughout the 1890s, he re-created out of those satisfying Tolstoyan plots smaller and more compromised survivors. In so doing Chekhov does not satisfy us less; but he does lay out for us the parameters of his distinctive type of comedy, which baffled Tolstoy until the end.

6 Relevant here are the comments on Chekhov's use of the "idea" in the final chapter of A. P. Chudakov's still unsurpassed Chekhov's Poetics. Chudakov argues that the idea as such - say, love - is not dogmatically developed in Chekhov's aesthetics, whether within a single consciousness or spread out along an entire plot. Unlike Dostoevsky and Tolstoy, ideas do not become more true the more wholly they are carried to their extreme ("As a matter of principle his ideas are not developed to their fullest"). Rather, their "truth" is always concrete, punctuated with interruption and shaped by the palpable details of everyday living. What matters for Chekhov is not so much the idea in itself as the "field of its existence" that constrains and shapes it. This principle results in a special sort of modesty vis-à-vis ideological resolution in general and the private lives of the protagonists in particular. Chekhov need not command any higher synthesizing vision, nor does he necessarily have access to the inner private worlds of his heroes (what, for example, Gurov lives by in his secret life). Tolstoy would never relinquish that knowledge. See A. P. Chudakov, Chekhov's Poetics, trans. Edwina Jannie Cruise \& Donald Dragt (Ann Arbor: Ardis, 1983), 191-216, esp. 192, 201. 